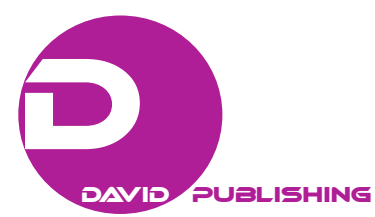

\title{
Social-economic Development of Small West European Peripheral Countries
}

\author{
Elena Efimova, Natalia Kuznetsova \\ St. Petersburg State University, St. Petersburg, Russia
}

\begin{abstract}
In the framework of different countries' international comparison, the objective of this paper reflects research topic of investigation - the identification of small countries, revealing features of economic development and business growth in economic history context of small economies classification. The object of investigation focuses on West European and Nordic countries' small economies. The hypothesis of the article is that small states under consideration are developing as the business competitive peripheries areas due to the special Scandinavian capitalist model development characterized by high level of social capital. The statistical data base includes Organization of Economic Cooperation and Development indicators, World Bank parameters and Nordic transnational corporation's annual reports. The paper considers the following research questions: (1) the critical overview of the mainstream academicians opinions concerning different-scaled economies, (2) classification of small states and clarification of different groups of the small-scaled countries role in the world and regional economy through historical context, (3) estimates and variants of small countries' social-economic development in accordance with different parameters, (4) consideration of Nordic European countries coming to the business model of the competitive peripheral social-economic development. The main summing up conclusion is that small economies of Nordic Europe are converting nowadays into the experimental laboratory of the European and world economy due to the specific model of their social-oriented economic and business growth, their geopolitical location between developed European integration complex embracing presumably small-scaled states from one side and large-scaled emerging market economy of Asian continent from the other side.
\end{abstract}

Keywords: small-scaled economies, spatial development, competitive (sub)periphery, social policy, Nordic multinational companies

\section{Introduction}

One of the academic problem that needs specific solution is the understanding of the role and place of different-scaled economies in the world development. Countries and regions of the global economy differ according to the level of economic, social, and political development, to their position and interrelationship with complex regional integration. The regional development is influenced by a set of factors: historical

Elena Efimova, professor, Doctor of Economics, Faculty of Economics, St. Petersburg State University, St. Petersburg, Russia.

Natalia Kuznetsova, professor, Doctor of Economics, Faculty of Economics, St. Petersburg State University, St. Petersburg, Russia..

Correspondence concerning this article should be addressed to Natalia Kuznetsova, Universitetskaja nabereznaja 7/9, 199034, St. Petersburg, Russia. Telephone/fax: 007812 2732400. E-mail: nataliakuz2010@yandex.ru. 
background, scale (demographic, territorial, and natural resources acquirement), and geographical position. The highly competitive long-term geopolitical communication among abundant large-scaled resource countries triggers small and ultra small areas to find out a unique chance to occupy a specific niche in the regional and world market. The research methods of the article deal with analysis-synthesis, historical, logical, and international comparison methods of investigation.

The paper deals with several issues, reflecting structure, logic and results of the paper: (1) literature review concerning the mainstream scientists opinions about small-scaled economies with the special reference to Russian scholars debates, (2) typology of small states and variants of their economic development, (3) estimates of economic growth of small countries according to different indicators, (4) Nordic European business convergence into the competitive peripheral sector of the world economy.

\section{Literature Review}

Until recently, the theory of small-scaled economy was not thoroughly developed in the Russian literature, though in the 1980s, a number of papers dedicated to the small countries of Western Europe (Judanov, 1984) have been published as well as some monographic research devoted to particular small countries of Northern Europe: Norway (Andreev, 1977), Sweden (Volkov, 1987, 2010), Denmark (Ebre, 1980; Gradobitova \& Ushakova, 1990), and Finland (Gradobitova \& Piskulov, 1972, 1986; Gradobitova, 1982.). It is necessary to mention that economic school of St. Petersburg State University and some publications focused on world economy countries typology with the special attention to the small-scaled developed countries, possessing natural (first of all mineral) resources and to small economies considered as the periphery in relation to the centers of the world economy and their specific place in regional complex integration (Kuznetsova, 1989, 1996, 2001, 2011). Recently, this direction of research has acquired a special significance in connection with some independent small states of the former USSR and the countries of Central and Eastern Europe formation, which appeared to be on different stages of economic development and to gravitate different integration groups. In these publications, it was observed that there is a special model of economic growth for the countries considered as small according to a number of indicators (Efimova, 2008). In a number of research, economic dynamics of different scaled states depend on a degree-a maturity of territorial structure of an economy, intensity of economic space usage, and population density (Mashbits, 1983; Odesser, 1986.). Saul (1982, p. 111) observed an idea that there exist some limits of growth of the population for the small countries, defined in density, natural, climatic, and historical conditions. This idea was argued by the analysis of the concrete economic historical data for the West European small countries from 1870 to 1914. Analysis of long-term dynamics (Kuznetsova, 2001, pp. 103-104) shows that industrialization in the small West European countries passed faster, smoother, and more rationally than that in the large-scaled economies. One of the important reasons of such phenomena lays in the relative ease of agrarian reforms, rather low social tension, constant inflow of the qualified and cheap labor from large West European countries captured by religious and civil wars. The small countries of Western Europe which have begun full-scope industrialization (1850-1870) later than large European states, implemented export orientation of the international specialization which can be defined as mono-cultural, directed to production by handicraftsmen-immigrants of a special kind of the raw goods and the high-quality products satisfying diversified European and world demand. For this reason, rate of labor productivity growth in the small countries was higher than that in large, observing its lower initial level. 


\section{International Comparison of Small Countries' Economic Development: Economic History View}

There are some variants of economic development of a small country owing to a various combination of territory, population, and the rate of its natural increase (Eccardt, 2005). The first subgroup of West European small countries, capable to expand the economic potential at the expense of industrial resources of its own, has a reserve for extensive economic growth (Spain, the Netherlands). A prototype of this model of development was demonstrated by the large immigration capitalist countries (including the USA, Canada and Australia) which managed to master the territory due to a high natural population increase, the mass immigration of capable, active, and initiative labor, and the regional integration complexes formation.

In the second subgroup of the small countries of investigated region are those which test an absolute lack of both raw-material natural resources and manpower, i.e. extensive factors of growth. The model of effective development here is dictated by the density of population and finding out chances for "raw-materials (natural or artificial) niche" formation. These countries' development is usually connected with intensification of their economic growth and involvement into regional integration complexes. The most part of developed West European states are such type of the small countries: Belgium, Luxembourg, Austria, Switzerland, Liechtenstein, Monaco, Andorra, San Marino, etc.. They possess small territory, traditionally high population density and small, sometimes negative rate of natural increase. The rate of natural increase (RNI) is calculated as the crude birth rate minus the crude death rate of a population. Nowadays (2007), more than 70 countries have a total fertility rate of less than two and hence negative RNI. Without immigration or an increase in total fertility rates, all these countries will have declining populations over the next few decades. International comparison of these groups of small countries' development demonstrates their significant inequality concerning scientific technical and technological development level, as well as rather big gap between most and least advanced countries accessing the break among different large countries.

The third subgroup is formed by the so-called peripheral countries of Western Europe. Besides the Mediterranean region, islands of the Central Atlantic and former colonial territories small countries of Northern Europe are included into this group. Peculiarities of small countries in Northern Europe are the relative geographical isolation, the limited resource base (first of all fertile soil, suitable for agricultural use) and rather low population density. Besides, these states could be referred to the so-called "Scandinavian social-oriented welfare model" with high level of social homogeneity, specific type of state-private partnership, and strong system of social processes governance. In particular, the Nordic countries are small and ethnically homogenous. Ethnic and religious homogeneity is conducive to the emergence of trust, the key component in "social capital". In fact, the level of trust is higher in the Nordic countries (and the Netherlands) than elsewhere according to available indicators, such as the European values survey. European values survey typically measures trust by the share of population who agree that "most people can be trusted". A high level of trust according to transparency international view is also associated with low corruption, which is essential for confidence in authorities and the acceptability of redistributive policies. Surveys suggest that the Nordic countries have an exceptionally low level of corruption.

\section{Development of Northern Countries-West European Competitive Periphery}

Economic development of Northern Europe countries according to Braudel (1979) was characterized by 
specific system of mutual relations between the central European (core) and peripheral (including Nordic) countries. The 1770-1870 century's industrial revolution was the trigger of this model of development. Geographical position of the Nordic states has predetermined a role of these countries in European regional system as European northern periphery (Kirby, 1995; Kuznetsova, 1995). Signs of periphery existence regarding geographical characteristics - remoteness from Frankfurt-am-Main (Busigina, 2004) and innovative activity character (primary implementation of applied R\&D compared to fundamental science further application), keep the former status of considered region as a periphery. At the same time, obvious social and economic achievements of Northern Europe economy allow to make addition to designated typology, naming this region competitive periphery (Creating Nordic Capitalism, 2008).

Overall market economy formation of Nordic countries passed through the classical scheme characteristic for the developed periphery scheme assuming internal and external components combination: the agrarian reforms creating the free labor market, successful international niche specialization in services and the industrial sphere acquiring an intensive R\&D introduction accompanied by transport and social infrastructure creation (Scott \& Storper, 1992). This classical scheme was demonstrated by Sweden, Denmark, Norway, and Finland. The completion of agrarian reforms was the main internal factor of their industrial development. The process of Nordic countries industrialization (1830-1920) was heavily influenced by significant foreign demand on Swedish iron ore and forest goods, Danish shipbuilding, chemical and the food-processing goods, Norwegian and Finish forest industrial goods: timber, pulp, and paper. Strengthening of the Nordic economies export orientation was promoted also by the activity of the national inventors. Among leading branches of the Swedish industry, specializing on export production were iron and steel industry metal working and mechanical engineering (Gerchikova, 1957). Nobel has played an important role in the largest Swedish military-industrial company "Bofors" development. Largest manufacturer firms "SKF" grew on ball-bearings patents implementation. Ericson has founded the future giant of his name "Ericson" on the basis of improved phone version. Lavalja's inventions have strongly strengthened positions of Sweden in the sphere of dairy production processing (Martinov, Grishin, \& Volkov, 2006, p. 58).

Most parts of export-oriented goods and services were produced in the largest multinational companies with home-country headquarters. A majority of the known Swedish firms which define global significance of the country nowadays were formed in 1870 to 1914. Author's calculation of exchange index OMXS30 in July, 2010 argued that according to the 30 largest Swedish multinational corporations list, $10(33.3 \%)$ have been created before 1900, seven (23.3 \%) in 1901 to 1918, and four (13.3 \%) in 1919 (Efimova \& Ulanov, 2011). Thus, only $30 \%$ of the biggest Swedish enterprises were created after the Second World War.

In Denmark, labor productivity and economic growth dynamics in agriculture caused domestic market and export expansion as well as emancipation of agrarian labor in favor of industrial sector. The country has created a set of large industrial enterprises: diesel-building concern "Burmeister and Wajn", the group "FL Smidth" (cement and mining industry equipment manufacturing and adjusting), brewery concern "Carlsberg", etc.. Before technological pattern shift (the fourth Kondratieff wave), Denmark (within the limits of cattle-breeding specialization) managed to implement intensive growth factors and conquer the guaranteed commodity markets (Great Britain, Germany), becoming one of leaders of the world food market in specific nomenclature of export production (bacon, butter). High labor productivity, exclusively high quality provision, and favorable terms of international food trade promoted accumulation of capital necessary for carrying out a set of structural reforms in the national economy. Machine-building companies either specialized in traditional branches (shipbuilding) 
or together with chemical and the food-processing industry served agrarian sector requirements. The Danish companies' policy during 1955 to 1965 has led to the transition of the Danish economy from agrarian-industrial to industrial-agrarian structure. Swedish and Danish firms acquired considerable scientific and technical potential in fundamental and applied R\&D during the period between the First World War and Second World War. Leading transnational corporations of national origin prospering mainly at the expense of foreign trade activities provided science financial provision. The following families of Nordic countries were and still are the leaders of R\&D implementation: Wallenberg, Johnsson, Broström in Sweden, Astrup, Ulsen, Wilhelmsen in Norway, A. P. Møller, F. L. Smidth in Denmark, Ehrnroth, Wahlforss, Wrede, Ahlstrom in Finland (Piskulov \& Gradobitova, 1972, p. 31). The leading position in R\&D is kept presumably by Swedish investment company "Investor" founded by the Wallenbergs in 1916.

Economic development of Norway and Finland during the national industrial organization formation was provided by the forest, paper, and pulp industry successes. However, intensive deforestation of Norway and its export to Great Britain by the beginning of the First World War have led to national wood resources exhaustion. Fisheries and marine freight became the basic export branches and stimulated the second stage of industrialization. Extraction of hydro carbonic raw materials on a continental shelf of Norway in the 1960s has coincided with the beginning of a postindustrial epoch and has predetermined catch-up of Norway into the information society as well as transformation of the resource-abundant country into one of the most advanced, knowledge-based economies of the world (Kuznetsova, 2011). Finland has kept its positions in world forest-industrial complex. The timber industry company "Ahlstrom" founded in 1851 now is included into the national list of the largest multinational corporations, keeping its traditional specialization.

In the 1960s, a new stage of innovational development of Northern European countries started. This process was connected with new industrial regions expansion outside of the world market mass production centers. The monetary distribution structure for scientific research and development used by multinational corporations of the Nordic countries is characterized by the smaller share of fundamental research funds compared to applied R\&D funds. This misbalance has been compensated by the government's support of fundamental research. The authorities give a priority to those areas of $R \& D$ in which scientific successes are the most obvious, for example, in Denmark in 1973 public funds have been distributed as follows: Fifty-three percent have gone on researches in the field of natural sciences and medicine, 29\% on agricultural and engineering sciences, $18 \%$ on social and humanitarian researches (Ebre, 1980, p. 13). Simultaneously applied $R \& D$ is traditionally financed by large business, for example, in Finland $70 \%$ of total investments on research and development are provided by private business.

In the mid of the 1970s, the central European and peripheral Nordic countries' relationship began to change gradually. The 1974-1975 world economic crises have influenced mining industry enterprises, ferrous metallurgy, shipbuilding, textile, etc.. Besides, cheap export and decrease in the productivity growth rates, observed in the late seventies, have led to the system of mass production world crisis as well as to the delay of regional development. Gradual refusal from mass production and product-oriented strategy, transition to more dynamical actions within the frame of the international industrial cooperation, to a client-oriented policy of customization, improvements of production process and innovative activity expansion are observed in Northern Europe businesses (Mintzberg, Lampel, Quinn, \& Ghoshal, 2003, pp. 361-369).

A basis of industrial companies of the North European region development happens to be concentric and 
conglomerate diversifications assuming revolutionary changes in the strategy of business, stimulating essential investments. These firms had acquired comparative advantages in expensive, unique scientific and labor-consuming production which due to the extremely high product quality does not meet adequate competition in the developed countries' markets. The companies of Northern Europe limited in their financial opportunities are compelled to choose less expensive narrow segment of the world market in which there exists an original invention or the specific "know-how" which is not interesting to the larger firms. The expert in an economic history of Norway wrote that the world market can give a chance to use small economy comparative advantages and to specialize in those spheres of the export-focused manufacture in which the small country has high competitiveness (Hodne, 1975, p. 6). This narrow and specific chosen niche allowed northern firms to occupy the maximum share of the world market. The Danish multinational corporation "FL Smidth" is the second manufacturer in Europe's fibro-cement building materials sector. Ninety-nine percent of its income is formed at the expense of foreign operations. Such specialization is not accompanied by big risks. It hides a danger of sharp falling of consumption of already ordered exported products during the crisis periods. Due to larger stability of the foreign trade deliveries within the limits of cooperation agreements in comparison with internal orders, export manufacture for a certain period of time supports the general level of a conjuncture in these countries in world down-swing stage.

One of the very specific features of the "Nordic capitalism" variant and these countries' business actors' development is private-state partnership in social policy implementation, due to the mentioned high level of social capital in socially homogeneous society.

\section{Nordic Countries Social Policy}

Northern European countries are characterized as welfare states, due to high tax rates and specific social policy. Social insurance and pension schemes have a broad coverage so far as all citizens have equal legal rights and chances, and are protected by a special employments policies based on classical social democratic triangle of state-business-trade-unions balance and system of bargaining. This balance does not depend on ability to pay or previous individuals tax payments which finance social sphere. Social protection is supported by relatively generous income replacement and flat-rate benefits. Scandinavian welfare state model and public protection are associated with income redistribution among different cohorts of population and highly subsidized by the state and business. The provision of welfare services tends to reduce the incidence and the risk of poverty. Nordic countries as a whole are characterized by a strong role of the public sector in child care, education, health and old-age care and pension's schemes.

Income and wealth differentials in the Nordic states are smaller than other countries in the world economy. Nordic businesses, governments, and individuals tend to proceed with the high rate of social equality, trust, low level of corruption and efficient public administration being factors and preconditions for egalitarian policies in the Nordic area. The latter could be figured out as a large welfare state space capable to process collective mechanisms of risk sharing and to execute the social programs, low and stable unemployment rate. The main objective of Nordic welfare state macroeconomic policies is the effective use of capital, labor, natural and social resources.

A number of global phenomenon-financial liberalization, the deep crises, and EU membership - triggered a reassessment of policies, paving the way not only for further deregulation but also for a new approach to macroeconomic policies and, to some extent, for acceptance of more flexibility in the capital 
and labor market. While the basic objectives remained unchanged, the big budget deficits associated with the crisis also led to a reconsideration of the public-sector and welfare-state policies, namely, some retrenchment of the public sector with cuts in benefit levels and subsequently in tax rates. The timing and sequencing differ among countries, but all Nordic areas have undertaken significant reforms of their public sectors and welfare policies in the past two decades.

International comparison shows that public sector in Nordic countries is still large. It absorbs a share of total income which is larger than that in other countries and the ratio of it exceeds other countries' indicators (Table 1). Social transfers are more heavily taxed in the Nordic countries than elsewhere.

Table 1

General Social Indicators of West European Countries

\begin{tabular}{|c|c|c|c|c|c|c|c|}
\hline Country & $\begin{array}{l}\text { Tax revenue } \\
\text { in } 2012, \% \text { of } \\
\text { GDP }\end{array}$ & $\begin{array}{l}\text { General } \\
\text { government } \\
\text { total outlays, } \\
\% \text { of GDP }\end{array}$ & $\begin{array}{l}\text { Total public social } \\
\text { expenditure in } \\
2013, \% \text { of GDP }\end{array}$ & $\begin{array}{l}\text { Total expenditure } \\
\text { on child care and } \\
\text { pre-primary in } \\
2009, \% \text { of GDP }\end{array}$ & $\begin{array}{l}\text { Average net } \\
\text { unemployment } \\
\text { replacement } \\
\text { rate, } 2010\end{array}$ & $\begin{array}{l}\text { Gross } \\
\text { replacement } \\
\text { rate in } \\
\text { pensions }\end{array}$ & $\begin{array}{l}\text { Progressivity } \\
\text { index of } \\
\text { pensions }\end{array}$ \\
\hline Austria & 43.2 & 51.8 & 28.3 & 0.4 & 52.0 & 76.6 & 27.9 \\
\hline Belgium & 45.3 & 54.2 & 30.7 & 0.7 & 64.5 & 41.4 & 57.0 \\
\hline Denmark & 48.0 & 57.7 & 30.8 & 1.4 & 40.2 & 83.7 & 56.8 \\
\hline Finland & 44.1 & 58,4 & 30.5 & 1.1 & 44.1 & 54.8 & 1.5 \\
\hline France & 45.3 & 57.0 & 33.0 & 1.1 & 49.2 & 59.1 & 30.4 \\
\hline Germany & 37.6 & 44.5 & 26.2 & 0.5 & 43.9 & 42.0 & 26.8 \\
\hline Greece & 33.8 & 47.9 & 22.0 & 0.1 & 23.1 & 64.0 & 40.2 \\
\hline Iceland & 37.2 & 47.2 & 17.2 & 1.7 & 42.5 & 73.8 & $\mathrm{n} / \mathrm{a}$ \\
\hline Ireland & 28.3 & 42.7 & 21.6 & 0.4 & 56.0 & 44.2 & 100.0 \\
\hline Italy & 44.4 & 51.4 & 28.4 & 0.7 & 23.4 & 71.2 & 1.4 \\
\hline Luxembourg & 37.8 & 43.9 & 23.4 & 0.4 & 29.9 & 59.3 & 21.8 \\
\hline Netherlands & 38.6 & 49.2 & 24.3 & 0.9 & 38.0 & 91.4 & 3.9 \\
\hline Norway & 42.2 & 44.8 & 29.2 & 1.2 & 38.4 & 52.3 & 43.9 \\
\hline Portugal & 32.5 & 46.3 & 26.4 & 0.4 & 52.0 & 55.0 & 1.0 \\
\hline Spain & 32.9 & 43.5 & 27.4 & 0.6 & 42.9 & 73.9 & 24.5 \\
\hline Sweden & 44.3 & 53.0 & 28.6 & 1.4 & 42.5 & 55.6 & -18.7 \\
\hline United Kingdom & 35.2 & 47.2 & 23.8 & 1.1 & 29.6 & 37.9 & 85.4 \\
\hline OECD-Average & 34.1 & 41.7 & 21.9 & 0.7 & $\mathrm{n} / \mathrm{a}$ & 57.9 & 38.5 \\
\hline
\end{tabular}

Source: Organisation for Economic Co-operation and Development (2013a, 2013b, 2013c, 2014a, 2014b) and DICE Database (2013).

Due to the data, the Nordic countries are not at the top of the list, though Sweden ranks high in terms of social expenditure relative to GDP. A particular feature of Nordic social policies is the high share of spending on child care and primary education, and the Nordics are also unique in spending as much as 3\%-4\% of GDP on families in the form of cash and services. The replacement rate is high in unemployment insurance and in pensions and is higher in the Nordic than that in the Anglo-Saxon area. Pensions in the Nordic countries have a low "progressivity index", meaning that benefits are strongly related to contributions and are therefore actuarially rather fair with exception for Denmark that has a quite generous flat-rate pension - schemes. Public spending in the Nordic countries is high, but a significant part of it is geared towards supporting a high rate of labor force participation. 
It is necessary to point out significant differences between the Nordic countries, but they are less than this differentiation compared to other European countries or other developed countries of the world. The Nordics have broadened their long-standing commitment to free trade in recent decades and modernized their collective mechanisms for risk sharing under the pressure of and in response to globalization.

But in Nordic area, the consequences of open competition on global markets are politically more acceptable, if for workers and local communities they are softened by social and labor market policies.

The coexistence or combination of collective mechanisms for risk sharing and openness to globalization is therefore no coincidence but a key feature of which might be regarded as the "Nordic model". It amounts to a system of generalized "flexicurity", the purpose of which is to help the economy and society to cope with risks and adapt to new requirements in times of rapid change.

\section{Conclusions}

Three options for classification of small developed countries allow explaining economic development according to various combinations of territory, population and primary historical-economic base. The highly developed countries of Northern Europe demonstrate a successful combination of the second and third variants.

The Nordic countries could be considered as West European competitive periphery proved by: (1) the high level of social and economic development of these countries and specificity of peripheral competitive character of their economy and business entities as well, (2) high level of social capital adequate to specific Nordic welfare state policies open to the challenges of global competition, and (3) sustainable commercial traditions and unique geo-political placement of Nordic area transforming the region into the business bridge of West-European sub-continent.

\section{References}

Andreev, J. V. (1977). Economics of Norway. Moscow: Nauka Publishing House.

Braudel, F. (1979). Material civilization, economics and capitalism in XV-XVIII centuries. Paris: Armand Colin.

Busigina, I. (2004). Enlargement of the EU through center-periphery concept. Cosmopolis, 1, 46-55.

Creating Nordic Capitalism. (2008). The business history of a competitive periphery. London: Palgrave Macmillan.

DICE Database (2013). Unemployment benefit replacement rates 1961-2011. Munich: Ifo Institute. Retrieved from http://www.cesifo-group.de/DICE/fb/37gR28zBH

Ebre, L. A. (1980). Economics of Denmark. Moscow: Publishing House Nauka.

Eccardt, Th. (2005). Secrets of the seven smallest states of Europe. New York: Hippocrene Books, Inc..

Efimova, E. G. (2008). Theoretical basics of regional transport infrastructure development: Case of Baltic Sea region. St. Petersburg: St. Petersburg University publishing House.

Efimova, E. G., \& Ulanov, V. A. (2011). Transnational corporations of Nordic European countries: Formation and stages of development. Vestnik Sankt-Peterburgskogo Universiteta. Economics, 5(1), 92-102.

Gerchikova, I. N. (1957). Foreign trade of Sweden after the II World war. Bulletin of foreign commercial information, 16, 1-3.

Gradobitova, L. D. (1982). Economic diplomacy of Scandinavian countries. Moscow: MGIMO Publishing House.

Gradobitova, L. D., \& Piskulov, J. V. (1972). North and integration. Moscow: Mezdunarodnye otnosheniya.

Gradobitova, L. D., \& Piskulov, J. V. (1986). Economy and policy of Scandinavian countries. Moscow: Mezdunarodnye otnosheniya.

Gradobitova, L. D., \& Ushakova, S. M. (1990). Denmark: Some aspects of socio-economic development. Moscow: Znanije Publishing House.

Hodne, F. (1975). An economic history of Norway 1815-1970. Bergen: Bergen University Publishing House.

Judanov, J. I. (1984). Small countries of West Europe. Moscow: MEiMO Academy of USSR Science Publishing House.

Kirby, D. G. (1995). The Baltic world 1772-1993: Europe's northern periphery in an age of change. London: Longman. 
Kuznetsova, N. P. (1989). Economic growth and capitalist reproduction intensification. Leningrad: Leningrad State University Publishing House.

Kuznetsova, N. P. (1995). Concept of Peripheral economy and economic growth specifics in the center and periphery. Vestnik of St.Petersburg State University Economics, 5(2), 69-74

Kuznetsova, N. P. (1996). Economic growth in historical context. St. Petersburg: St. Petersburg University Publishing House.

Kuznetsova, N. P. (2001). Economic growth: History and modernity. St. Petersburg: St. Petersburg University Publishing House.

Kuznetsova, N. P. (2011). Economic development in small and large transitional economies in transition from the energy-oriented to innovational-oriented type of economic growth. Mining Institute review, 191, 52-60.

Martinov, V. A., Grishin, I. V., \& Volkov, A. M. (2006). Swedish model of modern industrial and social development: New problems and characteristics. Moscow: MEiMO Academy of USSR Science Publishing House.

Mashbits, J. G. (1983). Developing countries: Main problems of economic and social geography. Moscow: Nauka Publishing House.

Mintzberg, H., Lampel, J., Quinn, J. B., \& Ghoshal, S. (2003). The strategy process. concepts, contexts, cases (4th ed.). London: Pearson Education Inc.

Odesser, S. V. (1986). Territorial structure of economy in developed capitalist countries typologies. Izvestija of USSR Academy of Science, 2, 84-85.

Organisation for Economic Co-operation and Development (2013a). OECD economic outlook. Retrieved from http://dx.doi.org/10.1787/eco_outlook-v2013-1-en

Organisation for Economic Co-operation and Development (2013b). Pensions at a glance 2013: OECD and G20 indicators. Retrieved from http://dx.doi.org/10.1787/pension_glance-2013-en

Organisation for Economic Co-operation and Development (2013c). Social Issues: Key tables from OECD. Retrieved from http://www.oecd-ilibrary.org/social-issues-migration-health/social-issues-key-tables-from-oecd_20743904

Organisation for Economic Co-operation and Development (2014a). Revenue statistics 2014. Retrieved from http://dx.doi.org/10.1787/rev_stats-2014-en-fr

Organisation for Economic Co-operation and Development (2014b). OECD family database. Retrieved from http://www.oecd.org/social/family/database.htmOECD

Saul, S. B. (1982). The economic development of small nations: the experience of North-West Europe in the XIX century economics in the long view. In Ch. P. Kinleberger, \& G. di Tella (Eds.), Economics in the long view (pp. 111-131). London: Macmillan.

Scott, A. J., \& Storper, M. (1992). Industrialization and regional development. In M. Storper, \& A. J. Scott (Eds.), Pathways to industrialization and regional development (pp. 3-20). London: Routledge.

Volkov, A. M. (1987). Modern Sweden economics (accumulation of capital problem). Moscow: Nauka Publishing House.

Volkov, A. M. (2010). Sweden: Social-economic model. Moscow: Nauka Publishing House. 